\title{
Correspondence
}

\section{On an Alternative Interpretation for the Application of Cara: A Response}

\section{Aditya Kolachana*, K Mahesh*, Clemency Montelle**, K Ramasubramanian*}

In her correspondence entitled "On an Alternative Interpretation for the Application of Cara", published in IJHS, 54.1 (2019), 104-107, Dr. Shylaja suggests some changes in our paper "Determination of Ascensional Difference in the Lagnaprakarana", published in IJHS, 53.3 (2018), 302-316. At the outset, we would like to thank Dr. Shylaja for studying our paper carefully and suggesting changes. Dr. Shylaja essentially makes two remarks regarding our paper:

1. She notes that the given formulae for the ascensional difference are applicable to all celestial bodies lying on the diurnal circle of the Sun, and not just the Sun alone, and recommends to replace 'Sun' with 'any celestial body' in the paper:

The paper assumes that the cara calculation is applicable for the sun only. Therefore one has to replace the word sun as 'any celestial body' all through the paper.

In this context she also recommends changing the caption of Fig. 6 :

Therefore, the figure caption needs to be rewritten...

2. She also suggests an alternative interpretation for verse 24 of the Lagnaprakarana:

I would therefore offer a translation as follows...
Below, we respond to these remarks.

\section{Response to the first remark}

The first remark is technically correct. However, the suggestion to replace 'Sun' with 'any celestial body' may not be appropriate. Numerous clues indicate that the author only had the ascensional difference of the Sun in mind when composing the verses. For instance, verse 18 gives a method of calculating the ascensional difference by employing the mahiguna or the radius of the Sun's diurnal circle. Verses 19 and 20 employ the arkāgraguna or the amplitude of the Sun at sunrise to determine the ascensional difference. Verses 21 and 22 again employ the radius of the Sun's diurnal circle, as well as the maximum ascensional difference of the Sun at a given latitude. It is only verse 23 that presents the formula corresponding to $\tan \phi \tan \delta$. Moreover, the subsequent verses of the Lagnaprakarana (see "Determination of Kälalagna in the Lagnaprakarana", IJHS, 54.1 (2019), 1-12) clearly make use of the Sun's position as well as its ascensional difference in determining the kālalagna. Hence, we feel that our interpretation of the verses to refer to the ascensional difference of the Sun alone seems more appropriate, and we would like to stand by that.

\footnotetext{
* Cell for Indian Science and Technology in Sanskrit, Indian Institute of Technology Bombay, Powai, Mumbai - 400076; Email: aditya.kolachana@gmail.com.

**University of Canterbury, New Zealand.
} 


\section{Response to the second remark}

Dr. Shylaja's suggested reinterpretation of verse 24 is far more problematic. The verse and our translation are as follows:

$$
\begin{aligned}
& \text { प्रातश्चरं वणिगजादिवशाद्धनर्णम् } \\
& \text { अस्तेऽन्यथा न तदहर्निशयोस्तु मध्ये। } \\
& \text { कार्यं त्रिपज्चमलवादिषु चानुपातात् } \\
& \text { नैवानुपातविधिरस्य घटीप्रसारे।।२४।। }
\end{aligned}
$$

At sunrise, the ascensional difference is positive or negative depending on [the Sun's position with regard to] Libra or Aries. While setting, it is otherwise. That should not be applied during midst of the day and night. And in case of third, fifth, etc., portions [of the day, the cara] should be calculated [afresh] successively. The rule of proportion for this (cara) will not be applicable in [setting] the motion of the clock (ghatiprasāra).

Dr. Shylaja would like to translate the verse as follows:

\begin{abstract}
For [an object on] the First Points of Libra and Aries, the cara is positive or negative before the meridian transit and the opposite after the transit. Between the day and night [of the object] the cara is zero. The calculations for cara should be carried out at intervals of the day, like the third, fifth etc [during day of the object] and cannot be interpolated like a clockwork.
\end{abstract}

There are many issues with the above translation. Firstly, verses $18-23$ give only the magnitude of the ascensional difference, but do not explain how it is to be applied in various scenarios such as when the Sun is in different quadrants, or at different times of the day. The first half of verse 24 explains this succinctly as we have explained in our paper. This does not come out in Dr. Shylaja's interpretation which only talks about objects on the first points of Libra and Aries. It is also problematic to translate प्रातः and अस्त as 'before the meridian transit' and 'after the transit'. It may be noted that in Sanskrit literature, the term प्रातः is employed in relation to the rise of the Sun only and not any celestial body as desired by Dr. Shylaja.

There are a few other issues in her interpretation of Sanskrit compounds, as well as the analysis of the verse. Without getting into details, we would like to conclude our response by acknowledging that the second half of verse 24 is indeed difficult to understand. However, given that the first half talks about the application of the ascensional difference at sunrise, sunset, and noon, it is natural that the second half of the verse discusses the application of this quantity at other times of the day. Our interpretation follows this line of reasoning. Hence, we do not find any compelling reason to modify our interpretation in light of this correspondence. We are however open to considering other persuasive interpretations. 